DOI: $10.31249 / \mathrm{rsm} / 2018.03 .14$

\title{
Д.А. Добрынин
}

\section{"МЕЖАУНАРОАНАЯ АМНИСТИЯ" И ЧЕХОСЛОВАЦКОЕ ПРАВОЗАЩИТНОЕ АВИЖЕНИЕ 1977-1989 гr.}

Аннотация. В статье речь идет о правозащитном движении в Чехословакии конца 1970-х - конца 1980-х годов. Описываются судьбы чехословацких диссидентов, рассматриваются формы их деятельности. Анализируется роль правозашитной организации «Международная амнистия» в чехословаџком диссидентском движении. Делается вывод о том, что чехословацкие власти рассматривали правозащитную деятельность как нарушение закона, которое могло угрожать социалистическому государству и обществу. А «Международная амнистия», поддерживая диссидентов, косвенно выступала против режима Коммунистической партии Чехословакии.

Ключевые слова: права человека, «Международная амнистия», Чехословакия, Хартия 77, «открытое общество», диссиденты.

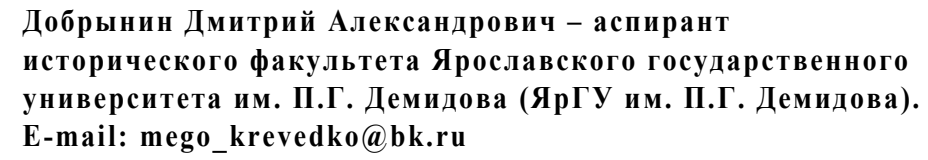

D.A. Dobrynin. «Amnesty International» and the Czechoslovak Human Rights Movement 1977-1989

Abstract. The article explores the human rights movement in Czechoslovakia in the late $1970 \mathrm{~s}-1980 \mathrm{~s}$ and describes the fate of the Czechoslovak dissidents as well as discusses the forms of their activities. The role of the human rights organization Amnesty international in the Czechoslovak dissident movement is analyzed. It is argued that the Czechoslovak authorities considered human rights activities as a violation of the law, which, in their opinion, could threaten the socialist state and society. Amnesty international, supporting dissidents, indirectly opposed the regime of the Communist party of Czechoslovakia.

Keywords: human rights, Amnesty International, Czechoslovakia, Charter 77, open society, dissidents. 


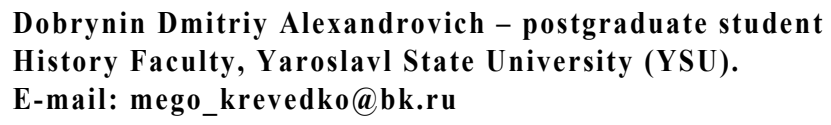

Литература по истории холодной войны обширна и многообразна. Среди специалистов достигнут консенсус по большинству проблем, считавшихся ранее дискуссионными. Вопросы, связанные с идеологическим противоборством, также подробно освещены современными авторами. Нельзя не упомянуть работы А.С. Маныкина, В.О. Печатнова, М.М. Наринского и др. [8; 9; 10]. Тем не менее этот период продолжает привлекать к себе внимание исследователей с точки зрения новых методологических и методических подходов. Особый интерес представляют вопросы, связанные с деятельностью неправительственных организаций и использованием «мягкой силы». В связи с этим представляется актуальным рассмотреть влияние «Международной амнистии» на ситуацию в социалистической Чехословакии. Обращение к этой стране обусловлено тем, что после подписания Заключительного акта Совещания по безопасности и сотрудничеству в Европе возникшее в ЧССР правозащитное движение во многом стало направляющим вектором в процессе демократизации общества не только в этой стране, но и на всем «советском пространстве» Центральной и Восточной Европы. Истории возникновения правозащитного манифеста, получившего название Хартия 77, и развития основанного на его идеях правозащитного движения посвящен целый ряд исследований Э.Г. Задорожнюк и других авторов $[3 ; 4 ; 5 ; 6]$.

В статье предпринята попытка на конкретных примерах проиллюстрировать деятельность правозащитников «Международной амнистии», направленную на поддержку подписантов Хартии 77. В основу методологического подхода исследования была положена концепция финской исследовательницы Пии Койвунен по изучению мягкой силы. Согласно предложенной концепции, основное внимание должно уделяться «малым акторам». Их воздействие рассматривается на нескольких уровнях. На микроуровне изучается взаимодействие между людьми (политзаключенными и правозащитниками), на промежуточном уровне - отношения «Международной амнистии» с диссидентскими организациями и властями. Следует отметить, что грань между микроуровнем и промежуточным далеко не всегда очевидна. На макроуровне отслеживается влияние «малых акторов» на ход холодной войны в целом или воздействие международных событий на характер взаимодействия низших уровней [30, p. 11-12]. 


\section{Исторический контекст возникновения Хартии 77 и Аеятельности "МежАународной амнистии"}

Период, получивший в исторической литературе название «застой», характеризует нарастание негативных явлений в экономической, социальной и политической сферах жизни социалистических обществ. В 1970-1980 гг. произошли серьезные изменения, связанные с идеологией. Будучи официальной, она постепенно превращалась в набор авторитетных мнений, не подлежащих критике. Характерной ее чертой было неприятие некоторых гражданских и политических прав человека (право на свободу передвижения, слова, собраний, объединений и др.). С одной стороны, начавшаяся политика разрядки и углубление сотрудничества между Западом и Востоком требовали от социалистических лидеров более гибкой позиции в вопросе прав человека, с другой - их соблюдение угрожало режиму. В связи с этим представляется уместным вспомнить события августа 1969 г. в Чехословакии, когда в годовщину «Пражской весны» сторонники А. Дубчека начали кампанию по отправке писем в ООН с требованием возврата к многопартийности и проведения свободных выборов [4, с. 77]. Постепенно в сознании партийных элит формировалось представление о том, что любые реформы угрожают социализму. Поэтому закономерно и появление «доктрины ограниченного суверенитета», или «доктрины Брежнева», которая легитимизировала вмешательство Советского Союза в дела стран соцблока.

Ввод войск стран ОВД в Чехословакию в 1968 г. оказал значительное влияние на оппозиционное движение, представители которого разочаровались в идеалах социализма и искали новую идеологическую платформу. Она была найдена в гуманитарных положениях Заключительного акта Совещания по безопасности и сотрудничеству в Европе (СБСЕ). С середины 1970-х годов инакомыслящие стали объединяться вокруг идеи прав человека. Этот процесс завершился 6 января 1977 г., когда была опубликована Хартия 77, ставшая манифестом чехословацких правозащитников. В тексте документа констатировалось, что в стране не соблюдаются основные положения Пакта о гражданских и политических правах (1966) [7] и Хельсинкского Заключительного акта (1975) [2]. Право на свободу выражения, по мнению авторов документа, было «чисто иллюзорным», а свобода слова ограничивалась цензурой. Были отмечены многочисленные случаи вмешательства государственных органов в частную жизнь: прослушивание телефонов, вскрытие почтовых отправлений, слежка за передвижением, формирование сети соседей-доносчиков. По сведениям авторов, власти страны оказывали давление на церковь; имели место многочисленные нарушения права на свободу совести [28]. Поэтому лица, подписавшие Хартию, объявили о создании свободного неформального открытого общества, основанного на принципе уважения прав человека [6, 
с. 396]. Участники движения дистанцировались от политических вопросов, провозгласив в качестве своей основной задачи привлечение внимания к нарушениям прав человека.

Прослеживается преемственность между «Пражской весной» и возникшим правозащитным движением. Опубликование текста Хартии 776 января 1977 г. стало символическим актом: 5 января 1968 г. А. Дубчек был избран первым секретарем ЦК КПЧ. Лидерами чехословацкого правозащитного движения стали Ян Паточка, Вацлав Гавел, Иржи Гайек. Последний в 1968 г. занимал пост министра иностранных дел ЧССР. В августе 1968 г. он с трибуны ООН назвал действия войск стран ОВД «оккупацией», благодаря чему стал широко известен на родине. В. Гавел в 1968 г. был уволен из театра за политическую активность. Все это указывает на оппозиционность авторов документа, которая сохранялась и в 1970-1980 гг. Сложно говорить о непредвзятом отношении к режиму со стороны чехословацких правозащитников, страдавших от преследований в период «нормализации» (1968-1989). Да и само представление о первичности прав отдельного человека противоречило марксистско-ленинской трактовке прав человека и в перспективе подразумевало установление принципиально иной модели государственного устройства.

Чехословацкие диссиденты ориентировались на мировое правозащитное движение и рассчитывали на широкое внимание со стороны международных организаций и прессы. На январь 1978 г. была запланирована белградская встреча Совещания по безопасности и сотрудничеству в Европе (далее СБСЕ). Публикация текста Хартии 77 напрямую связана с тем, что правозащитная организация «Международная амнистия» объявила 1977 год Годом узников совести. Это было особенно важно, поскольку реакцией официальных властей на возникновение в стране правозащитного движения стали аресты подписантов. Как следствие, создались благоприятные условия для деятельности правозащитников.

Продвигая западную модель прав человека, для которой было характерно признание первичности индивидуальных прав над коллективными, «Международная амнистия» выступала в качестве инструмента мягкой силы. Ее деятельность таила в себе угрозы для существования социалистических режимов.

Можно сказать, что «Международная амнистия» занималась созданием фундамента будущей постсоциалистической демократии в Чехословакии. Но следует учитывать, что сами по себе действия этой организации не могли привести к крушению режима. В Чехословакии существовало множество нерешенных внутренних проблем, служивших главным источником общественного недовольства. Вместо их разрешения власти начали преследовать неугодных. 


\section{Реакция властей Чехосповакии на Хартию 77 и первые шаги "МежАународной амнистии" (1977-1980)}

В январе 1977 г. генеральный прокурор ЧССР заявил о том, что в Хартии 77 содержатся призывы к «антиконституционной деятельности, подрывающей социалистический строй» $[30$, p. 2]. В. Гавел и несколько других активистов вскоре были арестованы. Уже к началу апреля 1977 г. почти каждый третий подписант был уволен с работы или обвинен в преступлениях против республики. Реакция «Международной амнистии» последовала незамедлительно. В марте 1977 г. был опубликован доклад о ситуации с правами человека в Чехословакии. По данным организации, за два месяца Хартию подписал 241 гражданин страны.

Особую обеспокоенность правозащитников вызвал тот факт, что диссиденты не могли апеллировать к международным институтам в области защиты прав человека. На начало 1977 г. ЧССР уже ратифицировала Международный пакт о гражданских и политических правах, Заключительный акт СБСЕ, но зачастую положения этих документов в стране не исполнялись. Чехословакия не присоединилась к Первому факультативному протоколу к Пакту о гражданских и политических правах ${ }^{1}$, поэтому граждане страны не могли обращаться в комитет ООН по правам человека. Все попытки расследовать случаи нарушения прав человека с привлечением международных институтов рассматривались правительством как вмешательство во внутренние дела.

Статьи Конституции ЧССР, касающиеся прав человека, в докладе «Международной амнистии» подвергались критическому анализу. Власти страны игнорировали обозначенные в основном законе страны положения, согласно которым граждане имели право на неприкосновенность жилища, свободу совести, могли свободно выражать свое мнение, участвовать в мирных собраниях, обращаться с петициями. Однако в своей деятельности правительство руководствовалось не конституцией, а набором партийных постановлений и ведомственных инструкций, зачастую противоречащих ей и нарушавших права человека.

В пресс-релизе за сентябрь 1977 г. «Международная амнистия» выразила глубокую обеспокоенность тем, что руководство ЧССР отказало в выдаче визы на въезд в страну британскому юристу Бернарду Симонсу, направленному в качестве наблюдателя на процесс по делу авторов Хартии 77 [15, p. 2].

1. В Первом факультативном протоколе оговаривается механизм контроля над соблюдением положений Международного пакта о гражданских и политических правах. Созданный комитет по правам человека имел право принимать жалобы, касающиеся нарушений прав человека, только от граждан стран, ратифицировавщих факультативный протокол [11]. 
Несмотря на усилия правозащитников, Вацлав Гавел был приговорен условно к 14 месяцам заключения, при этом до марта 1978 г. он находился в тюрьме. После освобождения в апреле 1978 г. В. Гавел объявил о создании «Комитета защиты несправедливо преследуемых». В течение последующего года многие сторонники этой правозащитной организации были обвинены в попытке свержения существующего строя и арестованы.

Другой подписант Хартии 77 журналист Иржи Лидерер в 1977 г. был осужден на три года содержания под стражей. Суровость приговора объясняется тем, что во время «Пражской весны» И. Лидерер работал в журнале «Корреспондент», редакция которого поддержала реформаторский курс А. Дубчека [16, p. 1]. В этом случае кампания «Международной амнистии» оказалась безрезультатной. Журналист отбыл полный срок наказания, после чего был выслан в ФРГ, где впоследствии работал в правительственной Комиссии по правам человека в Восточной Европе.

«Международная амнистия» несколько раз публиковала сведения об арестах друга В. Гавела чешского поэта и музыканта Ивана Мартина Йируса ${ }^{2}$. Его обвиняли в преступлениях против социализма, поскольку он являлся подписантом Хартии 77 и был связан с запрещенной рок-группой «Пластиковые люди Вселенной» [17, p. 1]. В 1970-1980 гг. его несколько раз арестовывали, но под давлением правозащитников каждый раз досрочно освобождали.

В сентябре 1978 г. «Международная амнистия» опубликовала информацию о священнике евангелической церкви Яне Шимса. По данным полиции, в его квартире часто проводились собрания диссидентов и правозащитников. Они обсуждали Хартию 77, Международный акт о гражданских и политических правах, Заключительный акт СБСЕ и другие документы в области защиты прав человека. Во время обыска в квартире Я. Шимса полицейский попытался силой отобрать у его жены конверт с письмом от одного из лидеров правозащитного движения Чехословакии Яна Паточки, а священник попытался воспрепятствовать этому. За нападение на сотрудника полиции при исполнении служебных обязанностей он был приговорен к восьми месяцам ареста. В этом случае «Международной амнистии» не удалось добиться смягчения наказания.

В сентябре 1978 г. правозащитная организация распространила информацию о деле чешского писателя Иржи Груши. После «Пражской весны» он был исключен из союза писателей и распространял свои произведения через самиздат, в 1977 г. подписал Хартию. Поводом к его аресту стала публикация в Канаде романа «Вопросник», в котором изобличались пороки социализма

2. Именно его арест и процесс по делу группы "Пластиковые люди Вселенной» в сентябре 1976 г. подвиг чехословачких диссидентов на создание текста Хартии 77 [1]. 
в Чехословакии. 1 июня 1978 г. Иржи Груша был арестован по обвинению в «разжигании ненависти и подстрекательстве к враждебным действиям». Благодаря своей известности на Западе и публикации «Международной амнистии», в ноябре 1978 г. он был освобожден и вскоре иммигрировал в Канаду $[18$, p. 1].

С делом И. Груши был связан арест другого чешского диссидента, Павла Рубалы. Будучи инженером по образованию, он создал в своей квартире несколько печатных станков. В подпольной типографии печатались запрещенные книги, в том числе и роман «Вопросник». Подпольное издательство обнаружили во время массовых обысков в Праге накануне визита Л.И. Брежнева летом 1978 г. [32, р. 40]. П. Рубала был обвинен в подстрекательстве к враждебным действиям. В сентябре 1978 г. «Международная амнистия» признала его узником совести, и в ноябре он был освобожден, после чего продолжил заниматься самиздатом.

В декабре 1978 г. «Международная амнистия» объявила заключенными месяца чешского агронома Алеша Махачека и физика-ядерщика Владимира Лаштувку, подписавших Хартию 77, распространявших ее текст и запрещенные в Чехословакии книги. Ученые были осуждены на три с половиной года заключения по обвинению в подготовке мятежа $[19$, р. 5]. Благодаря публикациям в 1980 г. узники совести были освобождены. В дальнейшем власти Чехословакии всячески препятствовали возобновлению их научной деятельности. В 1980 г. А. Махачека выслали из страны, а В. Лаштувку вплоть до бархатной революции был вынужден работать кочегаром.

Серьезную озабоченность правозащитников вызвало дело рабочего Мирослава Черны. Его обвинили в подстрекательстве к враждебным действиям и приговорили к трем годам лишения свободы. В действительности М. Черны, распространяя листовки, открыто критиковал насильственные методы борьбы, которые власти применяли против подписантов Хартии 77. Тюремное заключение негативно отразилось на здоровье осужденного: на фоне физического и морального истощения участились приступы эпилепсии. Признав его узником совести, «Международная амнистия» объявила о начале кампании за его освобождение [20, p. 3]. Сведения о деле М. Черны в период с 1978 по 1981 г. публиковались 5 раз, однако добиться смягчения наказания не удалось.

Наступление на оппозицию и рост числа дел, в которых усилия правозащитников не приносили ожидаемых результатов, были связаны с кризисом разрядки. В сентябре 1979 г. по стране прошла волна обысков и арестов. В результате 11 католических священников были арестованы за производство и распространение религиозной литературы. Среди них был иезуит Рудольф Шмахель, который во время «Пражской весны» принимал активное участие в студенческих протестах против ввода войск стран Варшавского договора 
и был лично знаком с Яном Палахом. Благодаря заметке в новостном письме «Международной амнистии» арестованных освободили на время следствия. В дальнейшем священники были приговорены к различным срокам тюремного заключения (от 20 месяцев до трех лет), поскольку так или иначе были связаны с событиями 1968 г., самиздатом и Хартией 77 [22, p. 4-5].

На рубеже 1970-1980 гг. власти продолжали вести борьбу против «Комитета защиты несправедливо преследуемых». 19 мая 1979 г. десять руководителей организации были вновь арестованы. «Международная амнистия» признала их узниками совести. После нескольких обращений активистов к руководителям ЧССР удалось добиться освобождения четверых задержанных. В октябре 1979 г. оставшиеся в заключении шесть членов «Комитета защиты несправедливо преследуемых» во главе с В. Гавелом были осуждены на срок до пяти лет по обвинению в подрывной деятельности. «Международная амнистия» незамедлительно признала их узниками совести, но попытки обжаловать приговор не увенчались успехом; уже в феврале 1980 г. в новостном письме организации констатировалось, что правительство ЧССР перестало реагировать на просьбы о помиловании подписантов Хартии 77 [23, p. 8]. Только в 1983 г., когда состояние здоровья В. Гавела, приговоренного к четырем с половиной годам тюрьмы, ухудшилось, его поместили под домашний арест.

С арестом руководства «Комитета несправедливо преследуемых» связан приговор по делу шахтера Вацлава Улмафа. Он самостоятельно изучал религиозную литературу и хотел связать свою жизнь со служением церкви. В декабре 1979 г. В. Улмаф направил знакомому британскому священнику письмо, в котором подверг критике приговор Вацлаву Гавелу и его сторонникам. 19 марта 1980 г. во время обыска в доме подозреваемого полиция обнаружила религиозные самиздатовские книги. В ходе следствия выяснилось, что В. Улмаф неоднократно отправлял письма в Министерство труда с требованием улучшить условия труда на шахте, а 25 декабря 1979 г., узнав о вводе советских войск в Афганистан, в присутствии других рабочих открыто осудил агрессивные, по его мнению, действия Советского Союза [24, p. 3]. В мае 1980 г. В. Улмаф был приговорен к трем годам лишения свободы. Для защиты руководителей «Комитета несправедливо преследуемых» и В. Улмафа в суде «Международная амнистия» направила своего наблюдателя австрийского адвоката Генри Гольдмана, который не был допущен в зал заседания. После вынесения приговора юрист остался в Чехословакии и занимался подготовкой апелляций. 20 декабря 1979 г. он был задержан, а затем выслан из страны. Власти Чехословакии объяснили свои действия тем, что иностранный адвокат вмешивался во внутренние дела страны [12, p. 260-264]. Сведения о деле В. Улмафа несколько раз публиковались в новостных письмах «Международной амнистии», но добиться его освобождения так и не удалось. 
В своих публикациях правозащитники дважды обращали внимание на дело чешского писателя Яромира Савдры, признанного в августе 1979 г. виновным в распространении нелегальной литературы и приговоренного к двум с половиной годам лишения свободы. Я. Савдра работал в подпольной типографии «Навесной замок». В 1980 г. «Международная амнистия» признала его узником совести, но последовавшая кампания за его освобождение была безуспешной [12, p. 260-264]. После освобождения в 1981 г. писатель присоединился к Хартии 77 и уже в сентябре 1982 г. был вновь арестован по обвинению в подстрекательстве к враждебным действиям. В июле 1983 г. «Международная амнистия» объявила его заключенным месяца, однако и в этот раз добиться досрочного освобождения Я. Савдры не удалось [28, p. 3].

В конце 1970 г. благодаря публикациям «Международной амнистии» удалось добиться освобождения восьми наиболее известных политзаключенных. Тем не менее пять узников совести отбыли полный срок наказания. При этом нельзя сказать, что усилия правозащитников оказались напрасными. В любом случае распространение информации об арестах подписантов Хартии 77 позитивно отражались на условиях содержания заключенных.

\section{Узники совести 1980-x гоАов}

В январе 1980 г. «Международная амнистия» признала узником совести пражского адвоката Йозефа Даниша, защищавшего в судах борцов за права человека. Формально он был арестован за публичное оскорбление официальных лиц и государственных органов. Благодаря публикациям правозащитников в мае 1980 г. он был отпущен на свободу по случаю очередной годовщины освобождения Чехословакии от нацистов [30, p. 8].

Обеспокоенные мероприятиями по защите подписантов Хартии 77, власти страны попытались дискредитировать правозащитников. 25 июня 1980 г. в еженедельной газете Коммунистической партии Чехословакии «Трибуна» была опубликована статья, посвященная деятельности «Международной амнистии». В заметке утверждалось, что организация «сфокусировала всю свою деятельность на Советском Союзе и социалистических странах» $[13$, р. 8]. Особо отмечено, что «дискредитируя в глазах населения коммунистические и рабочие партии по заданию западных спецслужб, активисты организации вмешиваются во внутренние дела других государств» [13, p. 285]. 21 октября 1980 г. в редакцию газеты от имени «Международной амнистии» поступило ответное послание, в котором указывалось, что организация работает во многих странах мира по мандату ООН. Правозащитники обратились к главному редактору газеты с просьбой опубликовать опровержение, но реакции со стороны издания не последовало. 
В начале 1981 г. «Международная амнистия» объявила узником совести Петра Цыбулку [13, p. 285], направленного на тяжелые работы, несмотря на его проблемы со здоровьем. В знак протеста против тяжелого труда и побоев заключенный объявил голодовку. В марте 1980 г. П. Цыбулку признали виновным в «воспрепятствовании цели содержания под стражей»: срок наказания увеличился на один год. В январе 1981 г. за оскорбление охранников срок был увеличен еще на десять месяцев [13, p. 288]. После очередной публикации «Международной амнистии» осужденный добился рассмотрения своей апелляции, и приговор был отменен 12 марта 1981 г. 16 марта 1981 г. исследовательское бюро организации направило президенту Чехословакии письмо, в котором приветствовало освобождение П. Цыбулки.

В марте 1981 г. в Праге и Братиславе были арестованы 30 сторонников Хартии 77. Во время расследования дела в мае 1981 г. на чехословацкоавстрийской границе были задержаны два гражданина Франции, которые пытались провести в ЧССР запрещенные книги и журналы, а также печатный станок и валюту. Это стало поводом для обвинения чехословацких правозащитников в «подрывной деятельности, осуществляемой при поддержке других государств». Состав преступления относился к числу особо тяжких и влек за собой наказание до десяти лет лишения свободы. В мае 1981 г. «Международная амнистия» заявила о признании восьми наиболее известных правозащитников, арестованных по данному делу, узниками совести. В результате бывший министр иностранных дел Чехословакии Иржи Гайек был немедленно освобожден [14, p. 262].

В июне 1981 г. «Международная амнистия» объявила узником месяца 40-летнего инженера Петра Ула. Он участвовал в работе над текстом Хартии 77 и был одним из учредителей «Комитета несправедливо преследуемых». В октябре 1979 г. вновь арестован на пять лет. Правительство Чехословакии продолжало игнорировать публикации правозащитников. В 1984 г. власти Чехословакии начали вновь преследовать П. Ула после его освобождения (частые задержания, обыски).

В документах «Международной амнистии», касающихся Чехословакии, часто встречаются сведения об арестах священнослужителей, не желавших согласовывать свои действия с властями. Например, в апреле 1982 г. организация признала узниками совести Ярослава Дуку и Франтишека Лизну. Первый обвинялся в препятствовании государственному надзору в церкви и был приговорен в декабре 1981 г. к 15 месяцам заключения, второй - к 20 за нанесение ущерба интересам республики за рубежом, так как отправил письмо своей сестре, иммигрировавшей в Великобританию $[25$, р. 3]. В октябре 1982 г. благодаря деятельности «Международной амнистии» был досрочно освобожден Я. Дука. Ф. Лизна отбывал полный срок, а в конце 1982 г. приговор по его делу был вновь пересмотрен в сторону увеличения. В общей 
сложности священник провел в заключении 27 месяцев и вышел на свободу только в июне 1983 г. Это объясняется тем, что в отличие от Я. Дуки Ф. Лизна подписал Хартию 77.

В 1984 г. «Международная амнистия» опубликовала сведения об аресте Иржи Вулфа, что вызвало большой общественный резонанс на Западе. В первый раз он попал в поле зрения правозащитной организации в 1978 г., когда был приговорен к трем годам заключения за распространение текста Хартии 77 [21, p. 2]. Как и во многих других случаях, добиться его досрочного освобождения тогда не удалось. 17 мая 1983 г. И. Вулф передал австрийскому послу в Праге сведения об условиях содержания политических заключенных в ЧССР. Через некоторое время эта информация была опубликована в ряде западных и чешских эмигрантских изданий. Правозащитник был немедленно арестован. 23 декабря 1983 г. приговорен к шести годам лишения свободы за «подрывную деятельность в сговоре с иностранными агентами». В мае 1984 г. «Международная амнистия» объявила о начале кампании в поддержку И. Вулфа, в которой принял участие американский конгрессмен Том Лантос. Однако власти Чехословакии не реагировали на призывы активистов организации [27, р.2]. И. Вулф вышел на свободу уже во время Бархатной революции [29].

1986 год ознаменовался новыми арестами инакомыслящих в Чехословакии. В апреле был задержан по обвинению в подстрекательстве и распространении запрещенной литературы Герман Хромой. Поводом к этому стало направленное им президенту страны письмо с критикой внутренней и внешней политики социалистических стран. В ходе следствия выяснилось, что Г. Хромой подписал Хартию 77 и часто слушал «Голос Америки». «Международной амнистии» не удалось добиться его освобождения. Диссидент вышел на свободу после отбытия двухлетнего срока в 1988 г. Аналогичное наказание было назначено Ярославу Швестке за цитирование произведений Д. Оруэлла. Спецслужбы обнаружили в его переписке сравнение ситуации в ЧССР с романом «1984». Отягчающим обстоятельством стало то, что адресат этого письма проживал в ФРГ. Я. Швестка был приговорен к трем годам лишения свободы, однако, благодаря публикации «Международной амнистии», срок наказания был уменьшен до одного года.

В 1988 г. «Международной амнистии» удалось добиться досрочного освобождения Петра Пошпишара, которому грозил немалый срок, поскольку у следствия имелись доказательства его связи с Хартией 77 и «Комитетом несправедливо преследуемых». Вдобавок к этому, в его доме была обнаружена переписка со сторонниками польского профсоюза «Солидарность» и картины запрещенных художников. Благодаря вмешательству «Международной амнистии» дело П. Пошпишара даже не попало в суд. Диссидент был отпущен, а его преследование было прекращено. 
Упомянутый выше список дел, в которых участвовали активисты «Международной амнистии», безусловно, не исчерпывающий, но уже на его примере можно сделать некоторые выводы о действенном влиянии этой правозащитной организации в ЧССР. Например о том, что в обозначенный период примерно в половине резонансных дел правозащитникам удавалось добиться досрочного освобождения узников совести. При этом следует подчеркнуть, что вокруг Хартии 77 сплотились люди разных возрастов, убеждений и профессий, что не позволяет их свести к единому социальному портрету «чехословацкого узника совести 1977-1989 гг.».

В качестве общего заключения отметим следующее. Возникновение чехословацкого правозащитного движения было одним из следствий «Пражской весны» и одной из форм протеста против ее подавления. Многие участники событий 1968 г. и лица, им симпатизировавшие, подписали Хартию 77. Опубликование текста документа было приурочено к «Году узников совести», объявленному «Международной амнистией». Сопричастность мировому правозащитному движению и идеологический нейтралитет, провозглашенные чехословацкими правозащитниками, предопределили широкую информационную поддержку «открытого общества» со стороны правозащитной организации, что было особенно важно в условиях начавшихся преследований чехословацких борцов за права человека. В период холодной войны и существования «доктрины Брежнева» правительство ЧССР не могло действовать иначе, поскольку для устранения причин возникновения правозащитного движения нужно было пойти на уступки в идеологическом плане, что было чревато серьезными последствиями.

«Открытое общество» стало полноценной структурой гражданского общества, которая постепенно отнимала у Коммунистической партии Чехословакии властные полномочия и моральный авторитет. Мероприятия «Международной амнистии» зачастую не приносили ожидаемых результатов. Во многих случаях правозащитникам не удавалось повлиять на судьбу узников совести. Это было обусловлено несколькими причинами. Во-первых, ситуация в области защиты прав человека начала стремительно ухудшаться после «Пражской весны» 1968 г., хотя в начале 1960-х годов уровень личной свободы в Чехословакии был едва ли не самым высоким среди социалистических стран. По этому показателю страна уступала только Польше. Во-вторых, усиление борьбы с подписантами Хартии 77 и невосприимчивость властей к замечаниям со стороны «Международной амнистии» были связаны с кризисом разрядки второй половины 1970-х годов и обострением международной напряженности в первой половине 1980 -х годов.

Между тем нельзя сказать, что усилия «Международной амнистии» были напрасными. Публикации о преследованиях инакомыслящих стали «невидимым щитом», не позволявшим властям страны эффективно противостоять 
растущему влиянию диссидентов. Внимание мирового правозащитного движения в тот момент было приковано к нарушениям гражданских и политических прав, составлявших основу западной идеологии и мягкой силы. Следовательно, гуманитарная деятельность организации являлась одним из инструментов, способствовавших реализации интересов западных стран в социалистическом мире. К концу холодной войны в Чехословакии сложилась парадоксальная ситуация: в стране существовало две власти. Коммунистическая партия утрачивала поддержку, но располагала обширной сетью силовых структур, подписанты Хартии 77 пользовались безусловным моральным авторитетом и оказывали огромное влияние на общество.

Многие узники совести, о которых говорилось выше, после Бархатной революции заняли высокие посты в сфере государственного управления. Так, идеолог правозащитного движения В. Гавел до Бархатного развода (1993) был президентом Чехословакии, а после него - Чехии. Бывший министр иностранных дел Чехословакии Иржи Хайек с 1990 по 1992 г. был советником председателя Федерального собрания А. Дубчека. Писатель Иржи Груша с 1990 г. являлся послом Чехословакии в ФРГ, с 1997 г. - министром образования Чехии, а в период с 1998 по 2004 г. был послом в Австрии. Петр Цыбулка в 2000 г. возглавил партию «Правый блок» и неоднократно участвовал в муниципальных и европейских выборах. Петр Ул в 1990-1992 гг. был депутатом Федерального собрания, с 1993 г. возглавлял комиссию по правам человека, с 2004 по 2007 г. - депутатом Европарламента от партии «Зеленых». Таким образом, можно констатировать, что в рамках правозащитного движения при поддержке «Международной амнистии» сформировалась группа политических деятелей, ориентированных на построение демократии по западному образцу.

\section{Библиография}

1. Добрынин Д.А. Иван Мартин Йирус - лидер чехословацкой культурной оппозиции // Герои и антигерои в мировой истории: Сб. статей участников Всероссийской научной конференции 9 июня 2017 г. Ярославль: Филигрань, 2017. С. 279-284.

2. Заключительный акт Совещания по безопасности и сотрудничеству в Европе. Хельсинки, 1975. 59 с. // ОБСЕ: Официальный сайт [Электронный ресурс]. URL: https://www.osce. org/ru/mc/39505?download=true (Дата обращения: 11.10.2017.)

3. Задорожнюк Э.Г. Вацлав Гавел - от диссидентства к президентству // Свободная мысль. 2010. № 12 (1619). С. 163-176.

4. Задорожнюк Э.Г. От крушения «Пражской весны» к триумфу Бархатной революции (август 1968 г. - ноябрь 1989 г). М.: Индрик, 2008. 440 с.

5. Задорожнюк Э.Г. Хартия 77 и концепция «параллельного общества» в Чехословакии // Новая и новейшая история. 2008. № 5. С. 84-98.

6. Задорожнюк Э.Г. «Режим нормализации» в Чехословакии и феномен «параллельного общества» // Власть и общество: Непростые взаимоотношения (Страны Центральной и ЮгоВосточной Европы в ХХ веке). М.: Институт славяноведения РАН, 2008. С. 390-421. 
7. Международный пакт о гражданских и политических правах. Принят резолюцией Генеральной Ассамблеи ООН 16 декабря 1966 г. // ООН: Официальный сайт [Электронный pecypc]. URL: http://www.un.org/ru/documents/decl_conv/conventions/pactpol.shtml (Дата обращения: 11.10.2017.)

8. Наринский М.М., Новиков Г.Н. Вопросы истории холодной войны: Сб. статей. М.: МГИМО, 2001. 113 с.

9. Основы общей теории международных отношений. М.: МГУ, 2009. 592 с.

10. Печатнов В.О. «Стрельба холостыми»: Советская пропаганда на Запад в начале холодной войны (1945-1947) // Сталинское десятилетие холодной войны. Факты и гипотезы. М.: Наука, 1999. С. 108-133.

11. Факультативный протокол к Международному пакту о гражданских и политических правах. Принят резолюцией Генеральной Ассамблеи ООН 16 декабря 1966 г. // ООН: Официальный сайт [Электронный ресурс]. URL: http://www.un.org/ru/documents/decl_conv/conventions/pactpro1.shtml (Дата обращения: 11.10.2017.)

12. Amnesty International Report. 1980. London: Amnesty International Publications, 1980. 409 p. // Amnesty International: Official Website [Электронный pecypc]. URL: https://www. amnesty.org/en/documents/pol10/0003/1980/en/ (Дата обращения: 21.09.2016.)

13. Amnesty International Report. 1981. London: Amnesty International Publications, 1981. 427 p. // Amnesty International: Official Website [Электронный pecypc]. URL: https://www. amnesty.org/en/documents/pol10/0001/1981/en/ (Дата обращения: 21.09.2016.)

14. Amnesty International Annual Report. 1982. London: Amnesty International Publications, 1982. 367 p. // Amnesty International: Official Website [Электронный ресурc]. URL: https://www. amnesty.org/en/documents/pol10/0004/1982/en/ (Дата обращения: 21.09.2016.)

15. Amnesty International Newsletter. 1977. Sept. Vol. VII. N 9 // Amnesty International: Official Website [Электронный pecypc]. URL: https://www.amnesty.org/en/documents/nws21/ 009/1977/en/ (Дата обращения: 28.09.2017.)

16. Amnesty International Newsletter. 1978. April. Vol. VIII. N 4 // Amnesty International: Official Website [Электронный pecypc]. URL: https://www.amnesty.org/en/documents/nws21/ 004/1978/en/ (Дата обращения: 21.09.2016.)

17. Amnesty International Newsletter. 1978. June. Vol. VIII. N 6 // Amnesty International: Official Website [Электронный pecypc]. URL: https://www.amnesty.org/en/documents/nws21/ 006/1978/en/ (Дата обращения: 21.09.2016.)

18. Amnesty International Newsletter. 1978. Sept. Vol. VIII. N 9 // Amnesty International: Official Website [Электронный ресурc]. URL: https://www.amnesty.org/en/documents/nws21/009/ 1978/en/ (Дата обращения: 21.09.2016.)

19. Amnesty International Newsletter. 1978. Dec. Vol. VIII. N 12 // Amnesty International: Official Website [Электронный ресурc]. URL: https://www.amnesty.org/en/documents/nws21/012/ 1978/en/ (Дата обращения: 21.09.2016.)

20. Amnesty International Newsletter. 1979. Feb. Vol. IX. N 2 // Amnesty International: Official Website [Электронный pecypc]. URL: https://www.amnesty.org/en/documents/nws21/002/ 1979/en/ (Дата обращения: 21.09.2016.)

21. Amnesty International Newsletter. 1979. Jan. Vol. IX. N 1 // Amnesty International: Official Website [Электронный ресурc]. URL: https://www.amnesty.org/en/documents/nws21/001/ 1979/en/ (Дата обращения: 21.09.2016.)

22. Amnesty International Newsletter. 1982. Aug. Vol. XII. N 8 // Amnesty International: Official Website [Электронный ресурc]. URL: https://www.amnesty.org/en/documents/nws21/008/ 1982/en/ (Дата обращения: 21.09.2016.) 


\section{РАЗМЫШЛЕНИЯ, СООБЩЕНИЯ, КОММЕНТАРИИ}

23. Amnesty International Newsletter. 1980. Dec. Vol. X. N 2 // Amnesty International: Official Website [Электронный pecypc]. URL: https://www.amnesty.org/en/documents/nws21/012/ 1980/en/ (Дата обращения: 21.09.2016.)

24. Amnesty International Newsletter. 1981. Feb. Vol. XI. N 2 // Amnesty International: Official Website [Электронный ресурc]. URL: https://www.amnesty.org/en/documents/nws21/002/ 1981/en/ (Дата обращения: 21.09.2016.)

25. Amnesty International Newsletter. 1982. April. Vol. XII. N 4 // Amnesty International: Official Website [Электронный ресурc]. URL: https://www.amnesty.org/en/documents/nws21/004/ 1982/en/ (Дата обращения: 21.09.2016.)

26. Amnesty International Newsletter. 1983. July. Vol. XIII. N 7 // Amnesty International: Official Website [Электронный ресурc]. URL: https://www.amnesty.org/en/documents/nws21/007/ 1983/en/ (Дата обращения: 21.09.2016.)

27. Amnesty International Newsletter. 1984. May. Vol. XIV. N 5 // Amnesty International: Official Website [Электронный ресурc]. URL: https://www.amnesty.org/en/documents/nws21/005/ 1984/en/ (Дата обращения: 21.09.2016.)

28. Charter-77 // The Freedom Collection: Official Website [Электронный ресурc]. URL: http://www.freedomcollection.org/artifacts/files/vaclav_charter77small.pdf (Дата обращения 20.07.2017.)

29. Czech Dissident Havel Freed, Vows to Speak Out // Los Angeles Times. 1989. May 18. URL: http://articles.latimes.com/1989-05-18/news/mn-349_1_vaclav-havel-dissident-czechoslovakauthorities (Дата обращения: 3.10.2017.)

30. Czechoslovakia: Amnesty International Briefing. 1981. 24 p. Amnesty International: Official Website [Электронный ресурc]. URL: https://www.amnesty.org/en/documents/eur16/009/ 1981/en/ (Дата обращения: 21.09.2016.)

31. Koivunen P. Performing Peace and Friendship. The Soviet Youth Festival as a Tool of Soviet Cultural Diplomacy. Tampere: University of Tampere, 2013. 372 p.

32. Návštěva genseka // Pamět' a Dějiny. 2013. N 1. P. 36-46.

\section{References}

Amnesty International Annual Report. 1982. London: Amnesty International Publications, 1982. 367 p. // Amnesty International: Official Website [Jelektronnyj resurs]. URL: https://www.amnesty. org/en/documents/pol10/0004/1982/en/ (Data obrashhenija: 21.09.2016.)

Amnesty International Newsletter. 1977. Sept. Vol. VII. N 9 // Amnesty International: Official Website [Jelektronnyj resurs]. URL: https://www.amnesty.org/en/documents/nws21/009/1977/en/ (Data obrashhenija: 28.09.2017.)

Amnesty International Newsletter. 1978. April. Vol. VIII. N 4 // Amnesty International: Official Website [Jelektronnyj resurs]. URL: https://www.amnesty.org/en/documents/nws21/004/ 1978/en/ (Data obrashhenija: 21.09.2016.)

Amnesty International Newsletter. 1978. Dec. Vol. VIII. N 12 // Amnesty International: Official Website [Jelektronnyj resurs]. URL: https://www.amnesty.org/en/documents/nws21/012/ 1978/en/ (Data obrashhenija: 21.09.2016.)

Amnesty International Newsletter. 1978. June. Vol. VIII. N 6 // Amnesty International: Official Website [Jelektronnyj resurs]. URL: https://www.amnesty.org/en/documents/nws21/006/1978/en/ (Data obrashhenija: 21.09.2016.)

Amnesty International Newsletter. 1978. Sept. Vol. VIII. N 9 // Amnesty International: Official Website [Jelektronnyj resurs]. URL: https://www.amnesty.org/en/documents/nws21/009/1978/en/ (Data obrashhenija: 21.09.2016.) 
Amnesty International Newsletter. 1979. Feb. Vol. IX. N 2 // Amnesty International: Official Website [Jelektronnyj resurs]. URL: https://www.amnesty.org/en/documents/nws21/002/1979/en/ (Data obrashhenija: 21.09.2016.)

Amnesty International Newsletter. 1979. Jan. Vol. IX. N 1 // Amnesty International: Official Website [Jelektronnyj resurs]. URL: https://www.amnesty.org/en/documents/nws21/001/1979/en/ (Data obrashhenija: 21.09.2016.)

Amnesty International Newsletter. 1980. Dec. Vol. X. N 2 // Amnesty International: Official Website [Jelektronnyj resurs]. URL: https://www.amnesty.org/en/documents/nws21/012/1980/en/ (Data obrashhenija: 21.09.2016.)

Amnesty International Newsletter. 1981. Feb. Vol. XI. N 2 // Amnesty International: Official Website [Jelektronnyj resurs]. URL: https://www.amnesty.org/en/documents/nws21/002/1981/en/ (Дата обращения: 21.09.2016.)

Amnesty International Newsletter. 1982. April. Vol. XII. N 4 // Amnesty International: Official Website [Jelektronnyj resurs]. URL: https://www.amnesty.org/en/documents/nws21/004/1982/en/ (Data obrashhenija: 21.09.2016.)

Amnesty International Newsletter. 1982. Aug. Vol. XII. N 8 // Amnesty International: Official Website [Jelektronnyj resurs]. URL: https://www.amnesty.org/en/documents/nws21/008/1982/en/ (Data obrashhenija: 21.09.2016.)

Amnesty International Newsletter. 1983. July. Vol. XIII. N 7 // Amnesty International: Official Website [Jelektronnyj resurs]. URL: https://www.amnesty.org/en/documents/nws21/007/1983/en/ (Data obrashhenija: 21.09.2016.)

Amnesty International Newsletter. 1984. May. Vol. XIV. N 5 // Amnesty International: Official Website [Jelektronnyj resurs]. URL: https://www.amnesty.org/en/documents/nws21/005/1984/en/ (Data obrashhenija: 21.09.2016.)

Amnesty International Report. 1980. London: Amnesty International Publications, 1980. 409 p. // Amnesty International: Official Website [Jelektronnyj resurs]. URL: https://www.amnesty.org/en/ documents/pol10/0003/1980/en/ (Data obrashhenija: 21.09.2016.)

Amnesty International Report. 1981. London: Amnesty International Publications, 1981. 427 p. // Amnesty International: Official Website [Jelektronnyj resurs]. URL: https://www.amnesty.org/en/ documents/pol10/0001/1981/en/ (Data obrashhenija: 21.09.2016.)

Charter-77 // The Freedom Collection: Official Website [Jelektronnyj resurs]. URL: http://www.freedomcollection.org/artifacts/files/vaclav_charter77small.pdf (Data obrashhenija: 20.07.2017.)

Czech Dissident Havel Freed, Vows to Speak Out // Los Angeles Times. 1989. May 18. URL: http://articles.latimes.com/1989-05-18/news/mn-349_1_vaclav-havel-dissident-czechoslovak-authorities (Data obrashhenija: 3.10.2017.)

Czechoslovakia: Amnesty International Briefing. 1981. 24 p. Amnesty International: Official Website [Jelektronnyj resurs]. URL: https://www.amnesty.org/en/documents/eur16/009/1981/en/ (Data obrashhenija: 21.09.2016.)

Dobrynin D.A. Ivan Martin Jirus - lider chehoslovackoj kul'turnoj oppozicii // Geroi i antigeroi v mirovoj istorii: Sb. statej uchastnikov Vserossijskoj nauchnoj konferencii 9 ijunja 2017 g. Jaroslavl': Filigran', 2017. P 279-284.

Fakul'tativnyj protokol k Mezhdunarodnomu paktu o grazhdanskih i politicheskih pravah. Prinjat rezoljuciej General'noj Assamblei UN 16 dekabrja 1966 g. // UN: Official Website [Jelektronnyj resurs]. URL: http://www.un.org/ru/documents/decl_conv/conventions/pactpro1.shtml (Data obrashhenija: 11.10.2017.)

Koivunen P. Performing Peace and Friendship. The Soviet Youth Festival as a Tool of Soviet Cultural Diplomacy. Tampere: University of Tampere, 2013. 372 p. 


\section{РАЗМЫШЛЕНИЯ, СООБЩЕНИЯ, КОММЕНТАРИИ}

Mezhdunarodnyj pakt o grazhdanskih i politicheskih pravah. Prinjat rezoljuciej General'noj Assamblei OON 16 dekabrja 1966 g. // UN: Official Website [Jelektronnyj resurs]. URL: http://www. un.org/ru/documents/decl_conv/conventions/pactpol.shtml (Data obrashhenija: 11.10.2017.)

Narinskij M.M., Novikov G.N. Voprosy istorii holodnoj vojny: Sb. statej. Moscow: MGIMO, 2001. $113 \mathrm{p}$.

Návštěva genseka // Pamět' a Dějiny. 2013. N 1. P. 36-46.

Osnovy obshhej teorii mezhdunarodnyh otnoshenij. Moscow: MGU, 2009. 592 p.

Pechatnov V.O. «Strel'ba holostymi»: Sovetskaja propaganda na Zapad v nachale holodnoj vojny (1945-1947) // Stalinskoe desjatiletie holodnoj vojny. Fakty i gipotezy. Moscow: Nauka, 1999. P. $108-133$

Zadorozhnjuk Je.G. «Rezhim normalizacii» v Chehoslovakii i fenomen «parallel'nogo obshhestva» // Vlast' i obshhestvo: neprostye vzaimootnoshenija (Strany Central'noj i JugoVostochnoj Evropy v XX veke). Moscow: Institut slavjanovedenija RAN, 2008. S. 390-421.

Zadorozhnjuk Je.G. Hartija 77 i koncepcija «parallel'nogo obshhestva» v Chehoslovakii // Novaja i novejshaja istorija. 2008. N 5. P. 84-98.

Zadorozhnjuk Je.G. Ot krushenija «Prazhskoj vesny»k triumfu Barhatnoj revoljucii (avgust 1968 g. - nojabr' 1989 g). Moscow: Indrik, 2008. 440 p.

Zadorozhnjuk Je.G. Vaclav Gavel - ot dissidentstva k prezidentstvu // Svobodnaja mysl'. 2010. N 12 (1619). P. 163-176.

Zakljuchitel'nyj akt Soveshhanija po bezopasnosti i sotrudnichestvu v Evrope. Hel'sinki, 1975. 59 p. // OSCE: Official Website [Jelektronnyj resurs]. URL: https://www.osce.org/ru/mc/39505? download=true (Data obrashhenija: 11.10.2017.) 